
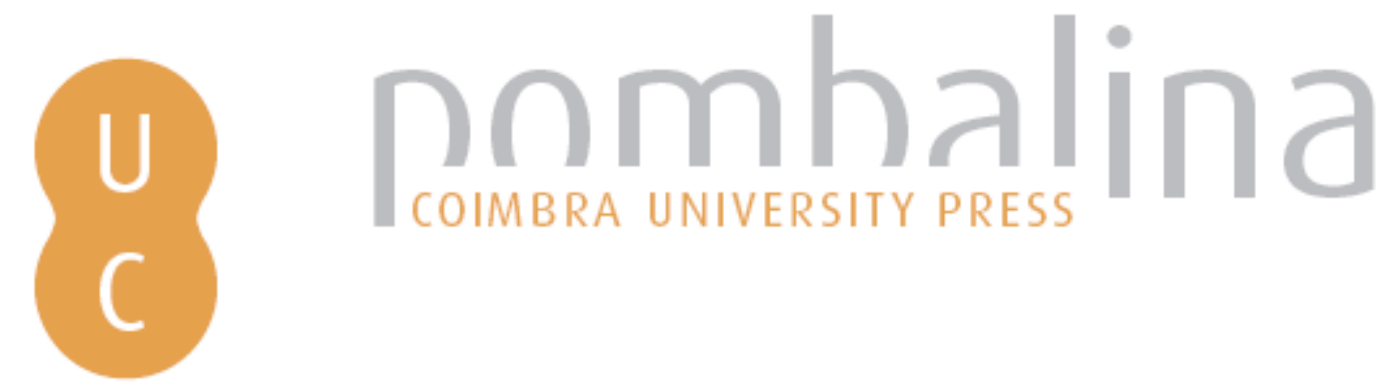

\title{
Formal Caregivers' health characterization and self-perception: implications for long- term care practicess
}

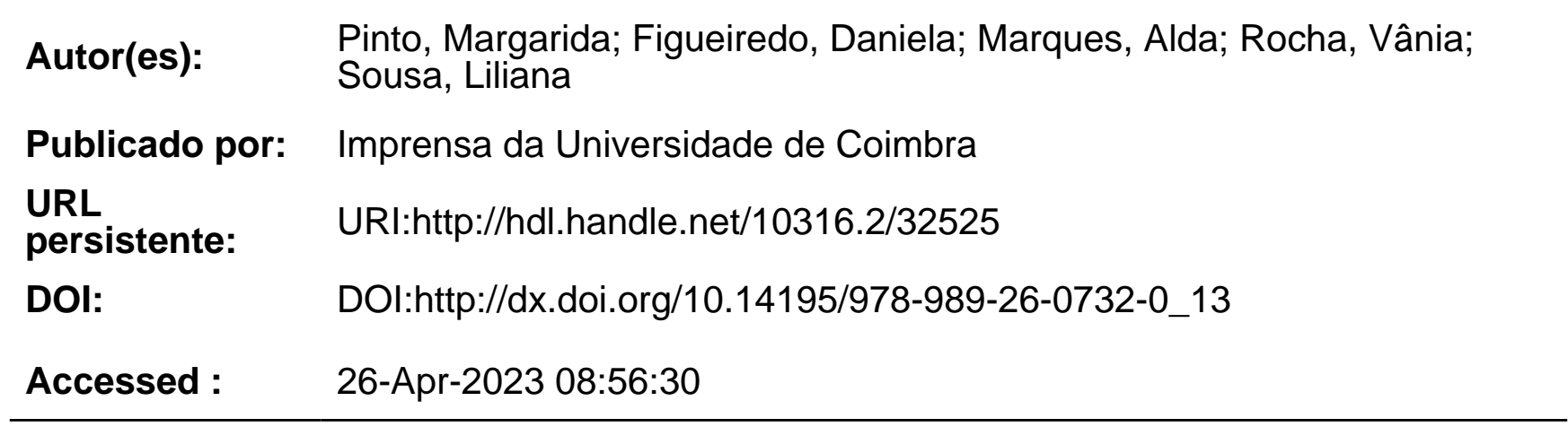

A navegação consulta e descarregamento dos títulos inseridos nas Bibliotecas Digitais UC Digitalis, UC Pombalina e UC Impactum, pressupõem a aceitação plena e sem reservas dos Termos e Condições de Uso destas Bibliotecas Digitais, disponíveis em https://digitalis.uc.pt/pt-pt/termos.

Conforme exposto nos referidos Termos e Condições de Uso, o descarregamento de títulos de acesso restrito requer uma licença válida de autorização devendo o utilizador aceder ao(s) documento(s) a partir de um endereço de IP da instituição detentora da supramencionada licença.

Ao utilizador é apenas permitido o descarregamento para uso pessoal, pelo que o emprego do(s) título(s) descarregado(s) para outro fim, designadamente comercial, carece de autorização do respetivo autor ou editor da obra.

Na medida em que todas as obras da UC Digitalis se encontram protegidas pelo Código do Direito de Autor e Direitos Conexos e demais legislação aplicável, toda a cópia, parcial ou total, deste documento, nos casos em que é legalmente admitida, deverá conter ou fazer-se acompanhar por este aviso.

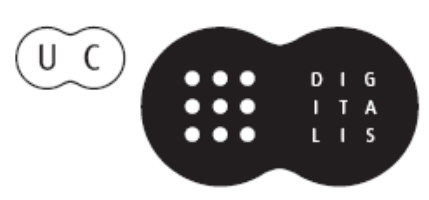


MPRENSA DA

UNIVERSIDADE

DE COIMBRA

COIMBRA

UNIVERSITY

- PRESS 


\title{
FORMAL CAREGIVERS' HEALTH CHARACTERIZATION AND SELF-PERCEPTION：IMPLICATIONS FOR LONG-TERM CARE PRACTICES
}

\author{
Margarida Pinto ${ }^{33}$, Daniela Figueiredo ${ }^{34}$, Alda Marques $^{35}$, \\ Vânia Rocha ${ }^{36}$, Liliana Sousa ${ }^{37}$
}

\begin{abstract}
Formal caregivers' health can affect the quality of care provided in long-term care settings. Therefore, this study aimed to analyze formal caregivers' health perception and how it varies according to socio-demographics, working conditions and other health-related variables. A cross-sectional study with 170 formal caregivers was performed in the central region of Portugal. A structured questionnaire based on International Classification of Functioning, Disability and Health Checklist (ICF-Checklist) was used to collect information about socio-demographic data, working conditions and health status. Formal caregivers reported a better perception of mental than physical health. Statistically significant differences in physical health perception were found according to age, educational levels, marital status, work experience, reasons for choosing job, medication intake, physical pain and functionality. Self-reported mental health was also significantly different according to educational levels, physical pain and functionality. The results highlight that formal caregivers mainly perceive themselves as being physically overloaded.

33 School of Health Sciences, University of Aveiro (ESSUA), Portugal.

34 Corresponding author: daniela.figueiredo@ua.pt; School of Health Sciences, University of Aveiro (ESSUA); Unidade de Investigação e Formação em Adultos e Idosos - UniFAI, Porto, Portugal.

35 School of Health Sciences, University of Aveiro (ESSUA), Portugal; Unidade de Investigação e Formação em Adultos e Idosos - UniFAI, Porto.

${ }^{36}$ School of Health Sciences, University of Aveiro (ESSUA), Portugal.

37 Unidade de Investigação e Formação em Adultos e Idosos - UniFAI, Porto; Department of Health Sciences, University of Aveiro (SACS), Portugal.
\end{abstract}


Thus, long-term care institutions should invest in interventions to prevent and alleviate physical and emotional overloads and promote strategies for self-care.

Keywords: Formal caregivers; Long-term care; Working conditions; Health

\section{Introduction}

The proportion of older people is growing faster than any other age group, particularly those aged $\geq 85$ years (Christensen, Doblhammer, Rau \& Vaupel, 2009). This population is highly susceptible to some health conditions, such as stroke (Marini et al., 2004), musculoskeletal disorders (Mottram, Peat, Thomas, Wilkie \& Croft, 2008), cancer (Lock \& Higginson, 2005), and dementia (Corrada, Brookmeyer, Paganini-Hill, Berlau \& Kawas, 2010), which lead to high levels of physical dependency and increased need for care and support. Therefore, it is expected that a greater number of older people, particularly the "oldest old", will require long-term care (Herrmann, Michel \& Robine, 2010).

Formal caregivers (also known as direct care providers, paid caregivers or support workers) represent a key-element in long term care institutions (Hussein \& Manthorpe, 2005). These professionals have the most direct contact with clients, are considered to be those primarily responsible for their well-being, and are often referred as the "eyes and ears" of the care system (Gage et al., 2009; Montgomery et al., 2005; Stone \& Dawson, 2008). They are defined as the workers who provide personal care (such as bathing, dressing, toileting and eating), support in instrumental activities of daily living, comfort, companionship and basic health care (administering medications and measuring vital signs) (Smith \& Baughman, 2007). Formal caregivers' interpersonal skills, technical abilities and well-being have great influence on the quality of care provided (Castle \& Engberg, 2007; Nolan et al., 2008). However, there are some barriers which could affect their well-being, such as long hours, poor pay (minimum wage), minimal benefits, few opportunities for job advancement and being prone to injury (Jorgensen et al., 2009; Mustard 
et al., 2010; Smith \& Baughman, 2007; Wilner, 2000). Moreover, formal caregivers have high work demands combined with low work control experience, job strain (Edvardsson et al., 2009), face persistent physical and mental demands and thus, are at risk of adverse health effects, which could affect their quality of work, well-being and may lead to absence from work (Menzel \& Robinson, 2006; Mustard et al., 2010).

In the last decade a growing number of studies regarding formal caregivers have emerged, focusing particularly on: (1) formal caregivers' socio-demographic profile (gender, age, education level, marital status) and work conditions (including wages, benefits, organization culture, and satisfaction) (Jorgensen et al., 2009; Montgomery et al., 2005; Potter et al., 2006; Smith \& Baughman, 2007; Wilner, 2000); (2) training and/or educational interventions (Aylward et al., 2003; Beer et al., 2010; Nolan et al., 2008); (3) the impact of work conditions on workers' satisfaction and performance (Ejaz et al., 2008; Kemper et al., 2008; Morris, 2009); and (4) stress and burnout (Duffy et al., 2009; Edvardsson et al., 2009; Jenkins \& Allen, 1998). However, little attention has been given to their health perception and associated factors. The existing studies focus on musculoskeletal injuries and are mostly targeted to professionals in the health sector (e.g., nurses) (Ando et al., 2000; Daraiseh et al., 2003; Jansen et al., 2004; Morse et al., 2008; Sveinsdóttir \& Gunnarsdóttir, 2008), neglecting the formal carers. Therefore, this study aimed to analyze formal caregivers' health perception and to explore its relationships with socio-demographics, working conditions and other health-related variables.

\section{Methods}

\section{Study Design}

A cross-sectional study was conducted in the central region of Portugal. Ethical approval was obtained by the Ethics Committee of the Research Unit of Health Sciences at the Health School of Nursing in Coimbra, Portugal. Written informed consents were obtained from participants. 


\section{Procedures}

Fifty-seven care homes were contacted and information about the study was provided to the service managers in an arranged meeting. Forty institutions agreed to participate. Formal caregivers were identified by the service managers and were included in the study if they: provided direct care services to dependent older people, such as personal care activities (bathing, dressing, toileting and eating), supervision and simple health care (administering medications and measuring vital signs); had worked in the care home for at least 6 months (steady regime); agreed to participate and sign the written consent form. Formal caregivers were excluded if they: were trainees or temporary workers; were responsible only for cleaning, transportation or meal preparation; had a specialization such as nurses, occupational therapists, physical therapists and social workers. A convenience sample of 170 formal caregivers was recruited. Data were collected between November of 2010 and September of 2011.

\section{Measures}

A structured questionnaire based on International Classification of Functioning, Disability and Health Checklist (ICF-Checklist) (World Health Organization, 2001) was used to collect data about socio-demographic (gender, age, education and marital status), working conditions and health status. The questions about formal caregivers' working conditions included: work experience in same care home (years), type of schedule (fixed or rotary) and the main reason for choosing the actual profession. Information to characterize caregivers' health included: height, weight, physical pain complaints (localization), medication intake, hospitalization (last year), sick leave (last 6 months), illness or injury that affected their functionality (last month), reduction in usual activities due to the health condition (illness, injury and/or pain) or due to the work (last month) and perception of physical and mental health (last month). 


\section{Analyses}

Statistical analyses were performed using the PASW Statistics 18.0 for Windows. Descriptive statistics were applied to characterize the sample. Data did not assume normality parameters; therefore non-parametric tests (Mann-Whitney test and Kruskal-Wallis test) were used to assess whether physical and health perception differed across socio-demographics, working conditions and health-related variables. The level of confidence considered was 0.05 .

\section{Results}

\section{Sample characterization}

Formal caregivers' mean age was $45.0 \pm 10.2$ years old. Most were female (99.4\%), married (67.6\%) and had 7 or more years of formal education (61.8\%) (Table 7).

Table 7: Socio-demographic characterization of the formal caregivers

\begin{tabular}{cc}
\hline Variable & $\mathrm{n}(\%)$ \\
\hline Gender & $169(99.4 \%)$ \\
Female & $1(0.6)$ \\
Male & \\
Age (years) & 0 \\
$\leq 20$ & $16(9.4 \%)$ \\
21 to 30 & $37(21.8 \%)$ \\
31 to 40 & $64(37.6 \%)$ \\
41 to 50 & $42(24.7 \%)$ \\
51 to 60 & $11(6.5 \%)$ \\
61 or more & \\
Education level (years) & $29(17.1 \%)$ \\
5-6 & $36(21.2 \%)$ \\
$7-9$ & $72(42.4 \%)$ \\
$10-12$ & $33(19.4 \%)$ \\
\hline Marital status & $115(67.6 \%)$ \\
Married & $10(5.9 \%)$ \\
Widowed & $26(15.3 \%)$ \\
Divorced or Separated & $19(11.2 \%)$ \\
Never married &
\end{tabular}




\section{Formal caregivers' working conditions}

Caregivers were working in the same workplace for $8.6 \pm 6.6$, mostly in rotating shifts $(68.2 \%)$. These workers were in this profession due to circumstantial reasons, i.e., unemployment, geographic proximity with the workplace or need to change job (61.8\%) (Table 8).

Table 8: Work conditions

\begin{tabular}{|c|c|}
\hline Variable & n (\%) \\
\hline \multicolumn{2}{|l|}{ Time at the same care home (years) } \\
\hline$\leq 5$ & $69(40.6 \%)$ \\
\hline 6 to 10 & $48(28.2 \%)$ \\
\hline 11 or more & $53(31.2 \%)$ \\
\hline \multicolumn{2}{|l|}{ Type of schedule } \\
\hline Fixed & $54(31.8 \%)$ \\
\hline Rotating & $116(68.2 \%)$ \\
\hline \multicolumn{2}{|l|}{ Main reason for choosing this profession } \\
\hline Circumstantial reasons & $105(61.8 \%)$ \\
\hline Liking & $63(37.1 \%)$ \\
\hline Other reasons & $2(1.2 \%)$ \\
\hline
\end{tabular}

\section{Formal caregivers' health characterization}

Most participants $(58.2 \%)$ were overweight or obese (BMI 25.00$)$ and were taking, at least one type of medication (53.5\%): anti-inflammatories (17.1\%), analgesics (15.3\%), anxiolytics/hypnotics (12.9\%), antidepressants (11.8\%), lipid-lowering (10.0\%), antihypertensive (8.2\%) and/or anti-diabetics (4.1\%). A total of 136 (80\%) formal caregivers complained of physical pain, particularly in their spine (64.1\%). Hospitalization in the last year was reported by $5.3 \%$ of the participants and the need to take sick leave by $15.9 \%$. Illness or injury affecting functionality was mentioned by $10.6 \%$ of the sample. Approximately half of the participants $(52.4 \%)$ reported a reduction in their usual daily activities (e.g., housekeeping, leisure), during the last month, due to work obligations/demands and $15.3 \%$ due to their health condition. Most of the participants considered their physical health as "good" $(47.1 \%)$ or "moderate" $(42.4 \%)$. The 
majority had a positive perception of their mental health, as $52.4 \%$ had considered it as "Good" (Table 9).

Table 9: Formal caregivers' health characteristics

\begin{tabular}{|c|c|}
\hline Variable & n $(\%)$ \\
\hline \multicolumn{2}{|l|}{ Body Mass Index (kg/m2) (WHO, 1995) } \\
\hline Normal $(18.50-24.99)$ & $71(41.8 \%)$ \\
\hline Overweight $(25.00-29.00)$ & $91(53.5 \%)$ \\
\hline Obese class - I, II, III $(\geq 30.00)$ & $8(4.7 \%)$ \\
\hline \multicolumn{2}{|l|}{ Medication Intake } \\
\hline At least, one type of medication intake & $91(53.5 \%)$ \\
\hline None & $79(46.5 \%)$ \\
\hline \multicolumn{2}{|l|}{ Types of medication } \\
\hline Anti-inflammatories & $29(17.1 \%)$ \\
\hline Analgesics & $26(15.3 \%)$ \\
\hline Anxiolytics/Hypnotics & $22(12.9 \%)$ \\
\hline Antidepressants & $20(11.8 \%)$ \\
\hline Lipid-Lowering & $17(10 \%)$ \\
\hline Antihypertensive & $14(8.2 \%)$ \\
\hline Anti-diabetics & $7(4.1 \%)$ \\
\hline \multicolumn{2}{|l|}{ Physical pain } \\
\hline No complaints & $34(20.0 \%)$ \\
\hline Presence of physical pain & $136(80.0 \%)$ \\
\hline \multicolumn{2}{|l|}{ Location of physical pain } \\
\hline Spine & $109(64.1 \%)$ \\
\hline Upper limb & $63(37.1 \%)$ \\
\hline Lower limb & $61(35.9 \%)$ \\
\hline Head & $14(8.2 \%)$ \\
\hline \multicolumn{2}{|l|}{ Hospitalization } \\
\hline Yes & $9(5.3 \%)$ \\
\hline No & $161(94.7 \%)$ \\
\hline \multicolumn{2}{|l|}{ Sick leave } \\
\hline Yes & $27(15.9 \%)$ \\
\hline No & $143(84.1 \%)$ \\
\hline \multicolumn{2}{|l|}{ Illness or injury that affected functionality } \\
\hline Yes & $18(10.6 \%)$ \\
\hline No & $152(89.4 \%)$ \\
\hline \multicolumn{2}{|l|}{ Reduction of daily activities due to work obligations/demands } \\
\hline Yes & $89(52.4 \%)$ \\
\hline No & $81(47.6 \%)$ \\
\hline \multicolumn{2}{|l|}{ Reduction of daily activities due to health condition } \\
\hline 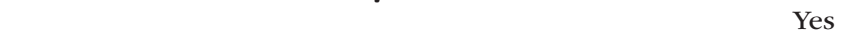 & $26(15.3 \%)$ \\
\hline No & $144(84.7 \%)$ \\
\hline \multicolumn{2}{|l|}{ Perception of physical health } \\
\hline Good & $80(47.1 \%)$ \\
\hline Moderate & $72(42.4 \%)$ \\
\hline Bad & $18(10.6 \%)$ \\
\hline \multicolumn{2}{|l|}{ Perception of mental health } \\
\hline Good & $89(52.4 \%)$ \\
\hline Moderate & $68(40.0 \%)$ \\
\hline Bad & $13(7.6 \%)$ \\
\hline
\end{tabular}




\section{Differences in health perception according to socio-demographics, working conditions and health-related variables}

Statistically significant differences in physical and mental health perception were found for education, physical pain and reduction in daily activities, i.e., participants with low educational levels, physical pain complaints and with reduction in daily activities reported a worse perception of physical and mental health (Table 10). No significant differences were found according to type of schedule, body mass index, hospitalization, sick leave and consumption of anxiolytic/hypnotic drugs. However, physical health perception was significantly different according to age, marital status, period of time working at the same workplace, reason for choosing the profession and functionality affected by illness/injury. Formal caregivers who had reported a worse health perception tended to be older, widowed or separated, with 5 or more years of work experience in the same care home and had chosen this profession for convenience. Furthermore, they also tended to consume analgesics, antidepressants or anti-inflammatory drugs and to report a decrease in their functionality due to illness/injury.

Table 10: Differences in the health perception (physical and mental) according to formal caregivers' characterization variables $(n=170)$.

\begin{tabular}{|c|c|c|c|c|c|}
\hline \multirow[b]{2}{*}{ Variable } & \multirow[b]{2}{*}{ n (\%) } & \multicolumn{2}{|c|}{$\begin{array}{c}\text { Self-Rated Physical } \\
\text { Health }\end{array}$} & \multicolumn{2}{|c|}{$\begin{array}{c}\text { Self-Rated Mental } \\
\text { Health }\end{array}$} \\
\hline & & M [IQR] & $\mathrm{P}$ & M [IQR] & $\rho$ \\
\hline $\begin{array}{r}\text { Age (years) } \\
21 \text { to } 30 \\
31 \text { to } 40 \\
41 \text { to } 50 \\
51 \text { to } 60 \\
61 \text { or more }\end{array}$ & $\begin{array}{r}16(9.4 \%) \\
37(21.8 \%) \\
64(37.6 \%) \\
42(24.7 \%) \\
11(6.5 \%)\end{array}$ & $\begin{array}{l}1[1,2] \\
1[1,2] \\
2[1,2] \\
2[1,2] \\
2[1,2]\end{array}$ & $0.034^{(2)}$ & $\begin{array}{l}2[1,2] \\
1[1,2] \\
1[1,2] \\
2[1,2] \\
2[1,2]\end{array}$ & $0.735^{(2)}$ \\
\hline $\begin{array}{r}\text { Education level (years) } \\
1-4 \\
5-6 \\
7-9 \\
10-12 \\
\end{array}$ & $\begin{array}{l}29(17.1 \%) \\
36(21.2 \%) \\
72(42.4 \%) \\
33(19.4 \%) \\
\end{array}$ & $\begin{array}{r}2[2,3] \\
1.50[1,2] \\
1.50[1,2] \\
1[1,2] \\
\end{array}$ & $0.000^{(2)}$ & $\begin{array}{l}2[1,2] \\
1[1,2] \\
1[1,2] \\
1[1,2] \\
\end{array}$ & $0.015^{(2)}$ \\
\hline $\begin{array}{r}\text { Marital status } \\
\text { Married } \\
\text { Widowed } \\
\text { Divorced or Separated } \\
\text { Never married }\end{array}$ & $\begin{array}{r}115(67.6 \%) \\
10(5.9 \%) \\
26(15.3 \%) \\
19(11.2 \%)\end{array}$ & $\begin{array}{r}1[1,2] \\
2[1.75,3] \\
2[1,2.25] \\
1[1,2]\end{array}$ & $0.006^{(2)}$ & $\begin{array}{r}1[1,2] \\
2 \\
{[1,2.25]} \\
2[1,2] \\
1[1,2]\end{array}$ & $0.115^{(2)}$ \\
\hline
\end{tabular}


Table 10 (cont.).

\begin{tabular}{|c|c|c|c|c|c|}
\hline $\begin{array}{r}\text { Time at the same care home } \\
\text { (years) } \\
\leq 5 \\
6 \text { to } 10 \\
11 \text { or more }\end{array}$ & $\begin{array}{l}69(40.6 \%) \\
48(28.2 \%) \\
53(31.2 \%) \\
\end{array}$ & $\begin{array}{l}1[1,2] \\
2[1,2] \\
2[1,2]\end{array}$ & $0.021^{(2)}$ & $\begin{array}{l}1[1,2] \\
2[1,2] \\
1[1,2]\end{array}$ & $0.397^{(2)}$ \\
\hline $\begin{array}{r}\text { Type of schedule } \\
\text { Fixed } \\
\text { Rotating }\end{array}$ & $\begin{array}{r}54(31.8 \%) \\
116(68.2 \%) \\
\end{array}$ & $\begin{array}{r}2[1,2] \\
1.5[1,2] \\
\end{array}$ & $0.241^{(1)}$ & $\begin{array}{r}1.5[1,2] \\
1[1,2] \\
\end{array}$ & $0.839^{(1)}$ \\
\hline $\begin{array}{r}\text { Main reason for choosing this } \\
\text { profession } \\
\text { Circumstantial reasons } \\
\text { Liking } \\
\text { Other reasons }\end{array}$ & $\begin{array}{r}105(61.8 \%) \\
63(37.1 \%) \\
2(1.2 \%) \\
\end{array}$ & $\begin{array}{r}2[1,2] \\
1[1,2] \\
---\end{array}$ & $0.018^{(2)}$ & $\begin{array}{r}2[1,2] \\
1[1,2] \\
---\end{array}$ & $0.133^{(2)}$ \\
\hline $\begin{array}{r}\text { Body Mass Index (kg/m2) } \\
\text { Normal } \\
(18.50-24.99) \\
\text { Overweight } \\
(25.00-29.00) \\
\text { Obese class - I, II, III }(\geq 30.00)\end{array}$ & $\begin{array}{r}71(41.8 \%) \\
91(53.5 \%) \\
8(4.7 \%) \\
\end{array}$ & $\begin{array}{l}2[1,2] \\
1[1,2] \\
2[1,2] \\
\end{array}$ & $0.717^{(2)}$ & $\begin{array}{l}2[1,2] \\
1[1,2]\end{array}$ & $0.141^{(2)}$ \\
\hline $\begin{array}{r}\text { Types of medication } \\
\text { Anti-inflammatories } \\
\text { None }\end{array}$ & $\begin{array}{r}29(17.1 \%) \\
141(82.9 \%)\end{array}$ & $\begin{array}{r}2[1.50,2.50] \\
1[1,2]\end{array}$ & $0.002^{(1)}$ & $\begin{array}{l}2[1,2] \\
1[1,2]\end{array}$ & $0.190^{(1)}$ \\
\hline $\begin{array}{l}\text { Analgesics } \\
\text { None }\end{array}$ & $\begin{array}{r}26(15.3 \%) \\
144(84.7 \%)\end{array}$ & $\begin{array}{r}2[1.75,2.25] \\
1[1,2]\end{array}$ & $0.003^{(1)}$ & $\begin{array}{l}2[1,2] \\
1[1,2]\end{array}$ & $0.114^{(1)}$ \\
\hline $\begin{array}{r}\text { Anxiolytics/Hypnotics } \\
\text { None }\end{array}$ & $\begin{array}{r}22(12.9 \%) \\
148(87.1 \%) \\
20(11.8 \%)\end{array}$ & $\begin{array}{l}2[1,2] \\
2[1,2]\end{array}$ & $0.361^{(1)}$ & $\begin{array}{l}2[1,2] \\
1[1,2]\end{array}$ & $0.055^{(1)}$ \\
\hline $\begin{array}{r}\text { Antidepressants } \\
\text { None }\end{array}$ & $150(88.2 \%)$ & $\begin{array}{r}2[1,2.75] \\
2[1,2] \\
\end{array}$ & $0.038^{(1)}$ & $\begin{array}{l}2[1,2] \\
1[1,2]\end{array}$ & $0.247^{(1)}$ \\
\hline $\begin{array}{r}\text { Physical pain } \\
\text { Presence of physical pain } \\
\text { No complaints } \\
\end{array}$ & $\begin{array}{r}136(80.0 \%) \\
34(20.0 \%) \\
\end{array}$ & $\begin{array}{l}2[1,2] \\
1[1,1] \\
\end{array}$ & $0.000^{(1)}$ & $\begin{array}{r}2[1,2] \\
1[1,1.25] \\
\end{array}$ & $0.002^{(1)}$ \\
\hline $\begin{array}{r}\text { Hospitalization } \\
\text { Yes } \\
\text { No }\end{array}$ & $\begin{array}{r}9(5.3 \%) \\
161(94.7 \%) \\
\end{array}$ & $\begin{array}{r}2[1,2.50] \\
2[1,2] \\
\end{array}$ & $0.617^{(1)}$ & $\begin{array}{l}2[1,2] \\
1[1,2]\end{array}$ & $0.827^{(1)}$ \\
\hline $\begin{array}{r}\text { Sick leave } \\
\text { Yes } \\
\text { No } \\
\end{array}$ & $\begin{array}{r}27(15.9 \%) \\
143(84.1 \%) \\
\end{array}$ & $\begin{array}{l}2[1,2] \\
2[1,2]\end{array}$ & $0.565^{(1)}$ & $\begin{array}{l}2[1,2] \\
1[1,2]\end{array}$ & $0.243^{(1)}$ \\
\hline $\begin{array}{r}\text { Illness or injury that affected } \\
\text { functionality } \\
\text { Yes } \\
\text { No }\end{array}$ & $\begin{array}{r}18(10.6 \%) \\
152(89.4 \%) \\
\end{array}$ & $\begin{array}{r}2[1.75,2.25] \\
1.50[1,2] \\
\end{array}$ & $0.015^{(1)}$ & $\begin{array}{r}1.50[1,2] \\
1[1,2] \\
\end{array}$ & $0.739^{(1)}$ \\
\hline $\begin{array}{r}\text { Reduction of daily activities } \\
\text { due to work obligations/de- } \\
\text { mands } \\
\text { Yes } \\
\text { No }\end{array}$ & $\begin{array}{r}89 \\
(52.4 \%) \\
81(47.6 \%) \\
\end{array}$ & $\begin{array}{l}2[1,2] \\
1[1,2]\end{array}$ & $0.009^{(1)}$ & $\begin{array}{c}2[1,2] \\
1[1,2]\end{array}$ & $0.007^{(1)}$ \\
\hline $\begin{array}{r}\text { Reduction of daily activities } \\
\text { due to health condition } \\
\text { Yes } \\
\text { No }\end{array}$ & $\begin{array}{r}26(15.3 \%) \\
144(84.7 \%) \\
\end{array}$ & $\begin{array}{r}2[2,2.25] \\
1[1,2] \\
\end{array}$ & $0.000^{(1)}$ & $\begin{array}{l}2[1,2] \\
1[1,2]\end{array}$ & $0.006^{(1)}$ \\
\hline
\end{tabular}

M - median; IQR - interquartile range [p25, p75]; (1) Mann-Whitney; (2) Kruskal-Wallis. 


\section{Discussion}

Formal caregivers tended to report a worse perception of physical than mental health. These results may be justified by their exposure to heavy workloads and high biomechanical difficulties. Previous studies have shown that musculoskeletal demands such as awkward postures, heavy lifting and repetitive movements negatively influence health (Bowers et al., 2003; Mustard et al., 2010; Pope, 2002; Roelen et al., 2007) and compromise well-being.

The statistically significant differences in physical health perception suggest negative physical impacts of the demands of care and alerts to the influence that age, marital status and education level could have on physical health perception. Caregivers with a worse self-reported physical health tended to be older, widowed, divorced or separated and had a lower education level. These findings were also supported by previous studies (Kelleher et al., 2003; Lambert et al., 2004). Ilmarinen (2001) suggested that the functional capacity to work for long periods and perform demanding and heavy tasks tends to decline after the fourth decade of life which could explain the influence of age found in this study. Additionally, marriage and a superior education level have been associated with a positive impact on life-style behaviors, improving self-esteem and self-efficacy (Lillard \& Panis, 1996; Winkleby et al., 1992).

Physical health perception was also different according to work conditions. Formal caregivers who reported a worse physical health perception had been working at the same institution for a longer period of time and had chosen this job for circumstantial reasons. As caregiving is a difficult job, with continuous musculoskeletal demands (Jorgensen et al., 2009; Mustard et al., 2010; Smith \& Baughman, 2007; Wilner, 2000) it is expected that it leads to caregivers' exhaustion (Jorgensen et al., 2009; Wilner, 2000) and therefore, influence their perception of physical health. Moreover, caregivers who chose this job for circumstantial reasons have less motivational factors that negatively influence their behaviors, satisfaction, performance and job commitment (Tadin et al., 2005). 
Furthermore, self-reported physical health differed significantly according to physical pain, medication intake (analgesics, anti-inflammatories and antidepressants), illness or injury that affected functionality and reduction of activities. Hard working conditions affect musculoskeletal outcomes in multiple body regions (Daraiseh et al., 2003; Mehlum et al., 2006), causing chronic pain and poor self-reported health status (Bergman et al., 2004; Roelen et al., 2008). Analgesics and/or anti-inflammatories are one of the possible ways to alleviate physical pain and are widely used to treat arthritis, sprains, painful periods and other painful conditions (INFARMED, 2011) commonly found in these workers (Boyer et al., 2009). Additionally, caregivers who reduced their daily activities also mentioned a worse self-related physical health. Demanding and repetitive tasks increase the risk of illness and consequently lead to a loss of productivity in the short term (Roelen et al., 2008) and long-term sickness absence (Roelen et al., 2007).

Mental health perception was related with educational level, physical pain and reduction of daily activities. As mentioned above, positive health behaviors are associated with a higher education level (Winkleby et al., 1992). Moreover, functional limitations, such as physical pain and reduction in daily activities, have a considerable impact on physical and mental health perception (Bergman et al., 2004).

Although this study provided a more comprehensive understanding of formal caregivers' profile in long-term care settings, our findings are limited by the exploratory nature of the research. Thus, further studies with a wider range of formal caregivers should be conducted, in order to include formal caregivers of dependent older people in different support services, such as home care services. Studies with specific subjective health measures are also needed in order to confirm the extent of our findings.

Nevertheless, some recommendations for long-term care settings can be retrieved. The results highlight the importance of institutional investment in occupational health by providing training/education to formal caregivers, work tools and standardized protocols for evaluating the handling and moving of patients as well as protocols to decide the number of workers needed (Ilmarinen, 2001; Ngan et al., 2010; Peled, 2005). 
Moreover, it is recommended that physical workloads should be adapted in line with advancing age, and appropriate work postures and the use of equipment aids should be promoted (e.g. transfer sling, gait belt and bath chair) which could facilitate the carrying out of tasks (Ilmarinen, 2001; Tuomi et al., 2001) and eventually reduce the pain and the need for anti-inflammatories and analgesics.

\section{Conclusion}

Although the role of formal caregivers in clients' well-being and quality of care have been recognized (Bowers et al., 2000; Castle \& Engberg, 2007), the importance of this workforce is still neglected by policies.

This study suggested that professionals caring for dependent older people are frequently exposed to distressing physical and emotional situations. More detailed knowledge on these workers in terms of health and associated factors, alert to the role of authorities and organizations in adjusting the workload to the functional capacities of caregivers, investing in interventions to prevent and alleviate physical and emotional overloads and promote self-care strategies. There is a growing demand for high-quality personalized care, and therefore it is essential to attract and qualify workers to the area of aging and create conditions for them to remain in this job.

\section{References}

Ando, S., Ono, Y., Shimaoka, M., Hiruta, S., Hattori, Y., Hori, F., et al. (2000). Associations of self estimated workloads with musculoskeletal symptoms among hospital nurses. Occupational and Environmental Medicine, 57, 211.

Aylward, S., Stolee, P., Keat, N., \& Johncox, V. (2003). Effectiveness of Continuing Education in Long-Term Care: A Literature Review. Gerontologist, 43, 259-271.

Beer, C. D., Horner, B., Almeida, O. P., Scherer, S., Lautenschlager, N. T., Bretland, N., et al. (2010). Dementia in residential care: education intervention trial (DIRECT); protocol for a randomised controlled trial. [Article]. Trials, 11, 63-68.

Bergman, S., Jacobsson, L. T. H., Herrström, P., \& Petersson, I. F. (2004). Health status as measured by SF-36 reflects changes and predicts outcome in chronic musculoskeletal pain: a 3-year follow up study in the general population. Pain, 108, 115-123. 
Bowers, B., Esmond, S., \& Jacobson, N. (2000). The Relationship between Staffing and Quality in Long-Term Care Facilities: Exploring the Views of Nurse Aides. Journal of Nursing Care Quality, 14, 55-64.

Bowers, B., Esmond, S., \& Jacobson, N. (2003). Turnover reinterpreted CNAs talk about why they leave. Journal of Gerontological Nursing, 29(3), 36-43.

Boyer, J., Galizzi, M., Cifuentes, M., d'Errico, A., Gore, R., Punnett, L., et al. (2009). Ergonomic and socioeconomic risk factors for hospital workers' compensation injury claims. American Journal of Industrial Medicine, 52, 551-562.

Castle, N., \& Engberg, J. T. (2007). The Influence of Staffing Characteristics on Quality of Care in Nursing Homes. Health Services Research, 42(5), 1822-1847.

Corrada, M., Brookmeyer, R., Paganini-Hill, A., Berlau, D. \& Kaeas, C. ( 2010). Dementia incidence continues to increase with age in the oldest old: The 90+ Study. Annals of Neurology, 67, 114-121.

Cristensen, K., Doblhammer, G., Rau, R. \& Vaupel, J. (2009). Ageing populations: the challenges ahead. The Lancet, 374(9696), 1196-1208

Daraiseh, N., Genaidy, A. M., Karwowski, W., Davis, L. S., Stambough, J., \& Huston, R. L. (2003). Musculoskeletal outcomes in multiple body regions and work effects among nurses: the effects of stressful and stimulating working conditions. Ergonomics, 46, 1178-1199.

Duffy, B., Oyebode, J. R., \& Allen, J. (2009). Burnout among care staff for older adults with dementia. Dementia, 8, 515-541.

Edvardsson, D., Sandman, P.-O., Nay, R., \& Karlsson, S. (2009). Predictors of job strain in residential dementia care nursing staff. Journal of Nursing Management, 17, 59-65.

Ejaz, F. K., Noelker, L. S., Menne, H. L., \& Bagaka's, J. G. (2008). The Impact of Stress and Support on Direct Care Workers' Job Satisfaction. Gerontologist, 48, 60-70.

Gage, H., Knibb, W., Evans, J., Williams, P., Rickman, N., \& Bryan, K. (2009). Why are some care homes better than others? An empirical study of the factors associated with quality of care for older people in residential homes in Surrey, England. Health E Social Care in the Community, 17, 599-609.

Herrmann, F., Michel, J. \& Robine, J. (2010). Worldwide decline in the oldest old support ratio. European Geriatric Medicine, 3-8.

Hussein, S., \& Manthorpe, J. (2005). An International Review of the Long-Term Care Workforce. Journal of Aging E Social Policy, 17, 75-94.

Ilmarinen, J. E. (2001). Aging Workers. Occupational and Environmental Medicine, 58, 546.

INFARMED. (2011). Prontuário Terapêutico (Vol. 10): Ministério da Saúde.

Jansen, J. P., Morgenstern, H., \& Burdorf, A. (2004). Dose-response relations between occupational exposures to physical and psychosocial factors and the risk of low back pain. Occupational and Environmental Medicine, 61, 972-979.

Jenkins, H., \& Allen, C. (1998). The relationship between staff burnout/distress and interactions with residents in two residential homes for older people. International Journal of Geriatric Psychiatry, 13, 466-472.

Jorgensen, D., Parsons, M., Reid, M. G., Weidenbohm, K., Parsons, J., \& Jacobs, S. (2009). The providers' profile of the disability support workforce in New Zealand. Health $\mathcal{E}$ Social Care in the Community, 17, 396-405.

Kelleher, C. C., Friel, S., Nic Gabhainn, S., \& Tay, J. B. (2003). Socio-demographic predictors of self-rated health in the Republic of Ireland: findings from the National Survey on Lifestyle, Attitudes and Nutrition, SLAN. Social Science E Medicine, 57, 477-486. 
Kemper, P., Heier, B., Barry, T., Brannon, D., Angelelli, J., Vasey, J., et al. (2008). What Do Direct Care Workers Say Would Improve Their Jobs? Differences Across Settings. Gerontologist, 48, 17-25.

Lambert, V. A., Lambert, C. E., Itano, J., Inouye, J., Kim, S., Kuniviktikul, W., et al. (2004). Cross-cultural comparison of workplace stressors, ways of coping and demographic characteristics as predictors of physical and mental health among hospital nurses in Japan, Thailand, South Korea and the USA (Hawaii). International Journal of Nursing Studies, 41, 671-684.

Lillard, L. A., \& Panis, C. W. A. (1996). Marital Status and Mortality: The Role of Health. Demography, 33, 313-327.

Lock, A. \& Higginson, I. (2005). Patterns and predictors of place of cancer for the oldest old. BMC Palliative Care, 4:6.

Marini, C., Baldassarre, M., Russo, T., De Santis, F., Sacco, S., Ciancarelli, I. \& Carolei, A. (2004). Burden of first-ever ischemic stroke in the oldest old. Evidence from a populationbased study. Neurology, 62(1), 171-181.

Mehlum, I. S., Kjuus, H., Veiersted, K. B., \& Wergeland, E. (2006). Self-reported work-related health problems from the Oslo Health Study. Occupational Medicine, 56, 371-379.

Menzel, N. N., \& Robinson, M. E. (2006). Back Pain in Direct Patient Care Providers: Early Intervention with Cognitive Behavioral Therapy. Pain Management Nursing, 7, 53-63.

Montgomery, R. J. V., Holley, L., Deichert, J., \& Kosloski, K. (2005). A Profile of Home Care Workers From the 2000 Census: How It Changes What We Know. Gerontologist, 45, 593-600.

Morris, L. (2009). Quits and Job Changes Among Home Care Workers in Maine: The Role of Wages, Hours, and Benefits. Gerontologist, 49, 635-650.

Morse, T., Fekieta, R., Rubenstein, H., Warren, N., Alexander, D., \& Wawzyniecki, P. (2008). Doing the heavy lifting: health care workers take back their backs. New Solutions, 18 (2), 207-219.

Mottram, S., Peat, E., Thomas, E., Wilkie, R. \& Croft, P. (2008). Patterns of pain and mobility limitation in older people: cross-sectional findings from a population survey of 18497 adults aged 50 years and over. Quality of Life Research, 17, 529-539.

Mustard, C., Kalcevich, C., Steenstra, I., Smith, P., \& Amick, B. (2010). Disability Management Outcomes in the Ontario Long-Term Care Sector. Journal of Occupational Rehabilitation, $20,481-488$.

Ngan, K., Drebit, S., Siow, S., Yu, S., Keen, D., \& Alamgir, H. (2010). Risks and causes of musculoskeletal injuries among health care workers. Occupational Medicine, 60, 389-394.

Nolan, M., Davies, S., Brown, J., Wilkinson, A., Warnes, T., McKee, K., et al. (2008). The role of education and training in achieving change in care homes: a literature review. Journal of Research in Nursing, 13, 411-433.

Peled, K. (2005). Workplace safety assessment and injury prevention in hospital settings. Work, 25, 273-277.

Pope, M., Goh, K. \& Magnusson, M. (2002). Spine Ergonomics. Annual Review of Biomedical Engineering, 4, 49-68.

Potter, S. J., Churilla, A., \& Smith, K. (2006). An Examination of Full-Time Employment in the Direct-Care Workforce. Journal of Applied Gerontology, 25, 356-374.

Roelen, C. A. M., Koopmans, P. C., de Graaf, J. H., van Zandbergen, J. W., \& Groothoff, J. W. (2007). Job demands, health perception and sickness absence. Occupational Medicine, 57, 499-504. 
Roelen, C. A. M., Schreuder, K. J., Koopmans, P. C., \& Groothoff, J. W. (2008). Perceived job demands relate to self-reported health complaints. Occupational Medicine, 58, 58-63.

Smith, K., \& Baughman, R. (2007). Caring for America's Aging Population: A Profile of the Direct-care Workforce. Monthly Labor Review, 130(9), 20-25.

Stone, R. I., \& Dawson, S. L. (2008). The Origins of Better Jobs Better Care. Gerontologist, $48,5-13$.

Sveinsdóttir, H., \& Gunnarsdóttir, H. K. (2008). Predictors of self-assessed physical and mental health of Icelandic nurses: Results from a national survey. International Journal of Nursing Studies, 45, 1479-1489.

Tadin, A., Rodrigues, J., Dalsoquio, P., Guabiraba, Z., \& Miranda, I. (2005). O Conceito de Motivação na Teoria das Relações Humanas. Revista de Ciência Empresariais, 2(1), 4047.

Tuomi, K., Huuhtanen, P., Nykyri, E., \& Ilmarinen, J. (2001). Promotion of work ability, the quality of work and retirement. Occupational Medicine, 51, 318-324.

Wilner, M. A. (2000). Toward a Stable and Experienced Caregiving Workforce. Generations, 24,60 .

Winkleby, M. A., Jatulis, D. E., Frank, E., \& Fortmann, S. P. (1992). Socioeconomic status and health: how education, income, and occupation contribute to risk factors for cardiovascular disease. American Journal of Public Health, 82, 816-820.

World Health Organization. (1995). Physical status: the use and interpretation of anthropometry.

World Health Organization. (2001). ICF Checklist. Geneva: World Health Organization. 